ORIGINAL ARTICLE / ARTIGO ORIGINAL

\title{
Social support and common mental disorder among medical students
}

\author{
Apoio social e transtorno mental comum entre estudantes de Medicina
}

\author{
Adriano Gonçalves Silva', Ana Teresa de Abreu Ramos Cerqueira", Maria Cristina Pereira Lima"
}

\begin{abstract}
Introduction: Different kinds of psychological distress have been identified for students in the health field, especially in the medical school. Objective: To estimate the prevalence of mental suffering among medical students in the Southeastern Brazil and asses its association with social support. Methods: It is a cross-sectional study. Structured questionnaires were applied for students from the $1^{\text {st }}$ up to the $6^{\text {th }}$ years of the medical school of Universidade Estadual Paulista "Júlio de Mesquita Filho", assessing demographic variables related to aspects of graduation and adaptation to the city. Psychological suffering was defined as a common mental disorder (CMD) assessed by the Self Reporting Questionnaire (SRQ-20). Social support was assessed by the social support scale of the Medical Outcomes Study (MOS). The association between the outcome and explanatory variables was assessed by the $\chi^{2}$ test and Logistic Regression, for the multivariate analyses, using $\mathrm{p} \leq 0.05$. Results: The response rate was of $80.7 \%$, with no differences between sample and the population regarding gender $(\mathrm{p}=0.78)$. The average age was 22 years old (standard deviation $-S D=2.2)$, mainly women $(58.2 \%)$ and students who were living with friends (62\%). The prevalence of CMD was $44.9 \%$ (95\%CI 40.2-49.6). After the multivariate analyses, the explanatory variables that were associated with CMD were: feeling rejected in the past year $(\mathrm{p}<0.001)$, thinking about leaving medical school $(\mathrm{p}<0.001)$ and "interaction" in the MOS scale $(p=0.002)$. Conclusions: The prevalence of CMD among medical students was high and insufficient social support was an important risk factor. Our findings suggest that interventions to improve social interaction among those students could be beneficial, decreasing the prevalence of CMD in this group.
\end{abstract}

Keywords: Common mental disorder. Social support. Students, medical. Cross-sectional studies. Education, medical.

'Hospital das Clínicas de Ribeirão Preto - Ribeirão Preto (SP), Brasil.

"Departamento de Neurologia, Psicologia e Psiquiatria da Faculdade de Medicina de Botucatu da Universidade Estadual Paulista "Júlio de Mesquita Filho" - Botucatu (SP), Brasil.

Corresponding author: Maria Cristina Pereira Lima. Departamento de Neurologia, Psicologia e Psiquiatria da Faculdade de Medicina de Botucatu da Universidade Estadual Paulista "Júlio de Mesquita Filho". Distrito de Rubião Júnior, s/n, CEP: 18618-000, Botucatu, SP, Brasil. E-mail: mclima@fmb.unesp.br

Conflict of interests: nothing to declare - Financial support: FAPESP. 
RESUMO: Introdução: Diferentes formas de sofrimento psíquico têm sido identificadas em estudantes da área da saúde, em especial no curso de Medicina. Objetivo: Estimar a prevalência de sofrimento psíquico entre estudantes de Medicina em uma faculdade no Sudeste do Brasil e avaliar sua associação com apoio social. Método: Trata-se de um estudo transversal. Foram aplicados questionários para alunos do $1^{\circ}$ ao $6^{\circ}$ ano do curso de Medicina da Universidade Estadual Paulista "Júlio de Mesquita Filho", investigando-se características demográficas relacionadas ao curso e à adaptação à cidade. Sofrimento psíquico foi investigado na forma de Transtorno Mental Comum (TMC), avaliado por meio do Self-Reporting Questionnaire (SRQ-20). Apoio social foi avaliado com a Escala de Apoio Social (EAS). As associações entre o desfecho e as variáveis explanatórias foram analisadas por meio do teste do $\chi^{2}$ e, na análise multivariada, por meio da Regressão Logística, com $\mathrm{p} \leq 0,05$. Resultados: A taxa de resposta foi de $80,7 \%$, não havendo diferença estatística entre a mostra e a população-alvo no que diz respeito ao gênero (p $=0,78$ ). A média de idade foi de 22 anos (desvio padrão - DP = 2,2) com predomínio de mulheres $(58,2 \%)$ e estudantes que vivem com amigos (62\%). A prevalência de TMC foi de 44,9\% (95\%CI 40,2-49,6). Após a análise multivariada, mantiveram-se associados a TMC: sentir-se rejeitado no último ano ( $\mathrm{p}<0,001)$, ter pensado ou pensar em abandonar o curso ( $\mathrm{p}<0,001)$ e "interação", avaliada pela EAS ( $\mathrm{p}=0,002)$. Conclusões: A prevalência de TMC entre estudantes de Medicina mostrou-se elevada, identificando-se o apoio social insuficiente como fator de risco. Esses achados sugerem que intervenções voltadas para propiciar melhores condições de interação social entre estudantes poderiam ser benéficas, diminuindo a prevalência de TMC nesse grupo.

Palavras-chave: Transtornos mentais comuns. Apoio social. Estudantes de Medicina. Estudos transversais. Educação médica.

\section{INTRODUCTION}

Different forms of mental suffering have been prevalent among students in the health field ${ }^{1}$. Even though it is not exclusive for medical students ${ }^{2,3}$, there is clear prevalence of studies about this population ${ }^{4}$. Several aspects have been mentioned as risk factors for mental distress, from the psychodynamic mechanisms of the individuals who choose this field ${ }^{5}$ until factors related to the structure of the course ${ }^{6,7}$, or even the characteristics of the professional practice ${ }^{8,9}$.

Most studies conducted in Brazil with populations of medical students investigated distress in the form of the so called common mental disorders (CMD). According to Goldberg and Huxley ${ }^{10}$, the CMDs are usually found in the population and indicate a mental suffering condition. According to these authors, there is an interruption in the usual functioning of the subject, but this situation is not always associated to a psychiatric diagnosis by the standardized criteria, for instance, by the International Classification of Diseases (ICD-10) of the World Health Organization ${ }^{11}$. It is relevant to identify such disorders, once they can cause damage and functional inabilities as much as chronic 
mental disorders ${ }^{12}$, being possibly associated to other health issues ${ }^{13}$. Studying the CMD is also relevant because the use of psychiatric nosological categories has been proven to be inadequate outside the psychiatric context, in which non-specific forms of mental distress prevail ${ }^{14}$.

The prevalence of CMD in national studies has ranged from 20 to $44 \%$, and individual and social ${ }^{15-19}$ characteristics have been pointed out as risk factors. Hidalgo et al. ${ }^{15}$, by using the Self-Reporting Questionnaire (SRQ-20), observed a positive association between insomnia and CMD, and found a $22.2 \%$ prevalence. Volcan et al. ${ }^{16}$ estimated a $20 \%$ prevalence for CMD, also using the SRQ-20, and spiritual well-being was demonstrated as a protective factor.

Facundes and Ludermir ${ }^{17}$ studied the prevalence of common mental disorder among students in courses of Physical Education, Nursing, Odontology and Medicine in Universidade de Pernambuco, trying to evaluate its association with characteristics of the teaching-learning process. They observed prevalence of $34.1 \%$, being higher among students who felt overwhelmed with academic activities and referred having lived special situations in childhood and adolescence. In this study, no comparisons were made between students from different $\operatorname{courses}^{17}$. Souza and Menezes18 investigated stress among medical students at Universidade Federal do Ceará, using another screening instrument for CMD, the General Health Questionnaire (GHQ), and observed prevalence of "psychological disorders" of 35.4\%, associated to the female gender and to students in the fifth semester of the course.

In the studies by Fiorotti et al. ${ }^{19}$ and Almeida et al. ${ }^{20}$, the prevalence of CMD was equally high. Almeida et al. ${ }^{20}$, in a study conducted with students from a medical school in Bahia, obtained CMD prevalence of $29.6 \%$, which was independently associated with changes in the sleeping pattern, not having private transportation, not working and not performing physical activities. In the analysis by Fiorotti et al. ${ }^{19}$, the prevalence of CMD was of $37.1 \%$, and the potential risk factors were: not receiving the necessary support and presenting difficulties to clarify any doubts in the classroom as a child or teenager.

Lima et al. ${ }^{21}$ observed high prevalence of mental distress (44\%) among medical students from a college in the countryside of São Paulo, associated to the following factors: not receiving the necessary emotional support, having difficulties to make friends, reporting regular/poor school performance, and thinking of leaving the course. In the mentioned study, the evaluation for not receiving the necessary emotional support increased the risk for CMD six times, even after the adjustment for potential confusing factors. These findings, as well as the ones observed by Fiorotti et al. ${ }^{19}$, suggest that the presence of insufficient local support is an important factor that should be specifically studied.

For a while, studies have shown that the presence of social support is associated with better results concerning health in general ${ }^{22}$. However, there are not many studies about this subject among medical students. Rospenda et al. ${ }^{23}$ observed there was an association 
between social support and academic performance, but they did not investigate mental disorders. Sreeramareddy et al. ${ }^{24}$, in a study conducted in Nepal, identified that the search for emotional support was an important strategy to face stressful situations, among others used by the students. The authors emphasized the need for further studies on the subject, and they also pointed out to the relevance of interventions in teaching institutions in order to provide better stress management.

This study aimed at estimating the prevalence of CMD among medical students and studying the association between psychosocial support and the presence of disorders. In the country, there are studies indicating the high prevalence of CMD, but there are no analyses concerning the social support issue - which motivated this investigation. As hypotheses, the expectation was that the prevalence of CMD was around 20 to $45 \%$, as in other investigations, and that the disorders were associated to insufficient social support.

\section{METHODS}

This is a cross-sectional observational study of independent samples in the different years of the medical school at Universidade Estadual Paulista "Júlio de Mesquita Filho" (UNESP). The school is located in Botucatu, São Paulo, a medium-sized city with about 120 thousand inhabitants. Most of the population is urban ${ }^{25}$. The target population were all of the students in the medical course at the time of data collection $(n=545)$. The inclusion criteria were: being regularly enrolled from the first to the sixth year of the medical course, attending classes on the day the instruments were being applied and consenting to participate in the research by signing the informed consent form. The application of the instruments occurred on dates that had been previously scheduled with the professors and in classes and disciplines that presented lower absence levels, except for those where tests were being applied.

A standardized, self-applicable questionnaire was used (available from the authors), which enabled to obtain data about the sociodemographic characteristics of the students and their respective families, such as gender, age, income, parents' schooling, among others. The questionnaire also had questions concerning adaptation to the city and frequency of visits to the families, since more than $90 \%$ of the students are not from the city where the college is located. The choice of variables to be included in the questionnaire considered the fact that they were pointed out as factors associated with CMD in previous studies, and because they were established as explanatory variables in this study, such as social support. So, the following structured and validated instruments were used.

\section{SOCIAL SUPPORT SCALE}

In order to assess social support, the Social Support Scale (SSS) was used, which had been originally elaborated for the Medical Outcomes Study, and then translated and 
adapted to Portuguese ${ }^{26}$. The choice for SSS considered that it presented the adequate psychometric qualities in another study with similar characteristics: literate population and self-application ${ }^{27}$. The scale has 19 items that approach 5 functional dimensions of social support: material (provision of practical resources and material help); affective (physical demonstrations of love and affection); emotional (positive affection expressions, comprehension and feelings of confidence); positive social interaction (availability of people to have fun or relax with) and information (availability of people to obtain advice or guidance from), as described by Griep et al. ${ }^{27}$. Since the SSS does not have a previously established cutoff point, two categories were created and called "sufficient" and "insufficient" in order to assess the obtained scores in each of the scale domains. Therefore, median and interquartile intervals were used. Scores up to the first quartile were classified as "insufficient" support, and scores above the first quartile were classified as "sufficient" support.

\section{Self-Reporting Questionnaire}

The SRQ-20 does not provide a psychiatric diagnosis, but it enables the evaluation of general mental health conditions, such as anxiety, insomnia and other symptoms of mental distress, which have been called common mental disorders ${ }^{14}$.

This instrument has been widely used in studies with several populations ${ }^{14}$, and also medical students ${ }^{15,16,18-20}$. There are 20 yes/no questions related to the month prior to the use of the instrument. In the study by Mari and Williams ${ }^{29}, 80 \%$ specificity and $83 \%$ sensitivity were obtained, with cutoff point of $7 / 8$. In this study, it was chosen to use different cutoff points for men (5/6) and women (7/8), as suggested by Mari and Williams ${ }^{28}$, once a lower positive predictive value was found for men in comparison to women when the cutoff point $7 / 8$ was employed for both genders ( 66 and $83 \%$, respectively). The instrument can be used by an interviewer or it can be self-applied, but the same strategy should be adopted for all of the individuals.

\section{Procedures}

The questionnaire of this study was previously applied in a group of six medical students, in order to estimate the necessary time for the answers, to assess comprehension in relation to the questions and to identify possible flaws in the instrument. The application of the questionnaires occurred in the classrooms after the previous schedule with the teachers in charge of the disciplines. After the objectives of the study were explained, the students were asked to sign the informed consent form, in case they agreed to it, and to insert their answers directly in the questionnaire. 


\section{Statistical analysis}

Data were typed into an electronic worksheet and analyzed with the software STATA $10.0^{29}$. At first, there was a descriptive analysis, when data consistency was checked and measures of central tendency were obtained, as well as variability and simple frequency tables, and corrections were made when necessary. The presence of CMD assessed by SRQ-20 was considered as the outcome of interest. The main explanatory variable was social support, assessed by SSS. The associations were analyzed by the $\chi^{2}$ test or the Fischer's exact test, when appropriate, and the $95 \%$ confidence interval was considered $(95 \% \mathrm{CI})$. Crude and adjusted odds ratio were calculated by means of the backward stepwise method to control confusing variables. Variables with $\mathrm{p}<0.25$ obtained in the univariate analysis were included in the model, and those with $\mathrm{p} \leq 0.05$ in the Wald test were considered to be significant in the multivariate analysis ${ }^{30}$.

\section{Ethical considerations}

The project was approved by the Research Ethics Committee of the medical school of Botucatu, after the approval of the council in the Graduate Medical Course. Students were informed about the objectives and procedures of the study, and their consent was requested only after the people who would apply the questionnaire explained about the research. After the informed consent form was filled out, it was detached from the rest of the questionnaire and kept separately, in order to make sure the identity of the participants and the obtained information would remain absolutely in secrecy. The possibility of getting in touch with the authors in charge of the project at any time was assured. All of the participants were told that no data would be individually publicized, and that only consolidated and grouped data would be object of scientific publication.

\section{RESULTS}

From a target-population of 545 enrolled medical students, 440 participated in the study, therefore, the response rate was of $80.7 \%$. Since six participants did not answer the SRQ20 , it was not possible to classify them as to the presence of CMD and, therefore, they were excluded from the study. Therefore, the sample was comprised of 434 students. With the objective of controlling non-response, the sample of this study $(n=434)$ was compared to the target-population $(n=545)$ in relation to gender, and statistically significant differences were observed $(\mathrm{p}=0.78)$. Mean age was 22 years old (standard deviation $-\mathrm{SD}=2.3$ ), ranging from 19 to 29 years old.

In Table 1 it is possible to observe the sample characteristics. Even though the participation rate was expressive, there was major loss among students in the last year 
Table 1. Social and demographic characteristics of medical students from Universidade Estadual Paulista "Júlio de Mesquita Filho", according to gender ( $\mathrm{n}=434)$.

\begin{tabular}{|c|c|c|c|c|c|}
\hline & \multicolumn{2}{|c|}{$\begin{array}{c}\text { Men } \\
n=182(41.9 \%)\end{array}$} & \multicolumn{2}{|c|}{$\begin{array}{c}\text { Women } \\
\mathrm{n}=252(58.1 \%)\end{array}$} & $\mathrm{p}$-value \\
\hline \multicolumn{5}{|l|}{ Year of the course } & $0.78^{*}$ \\
\hline 1 & 33 & 18.1 & 50 & 19.8 & \\
\hline 2 & 27 & 14.8 & 47 & 18.6 & \\
\hline 3 & 34 & 18.7 & 38 & 15.1 & \\
\hline 4 & 29 & 16.0 & 44 & 17.5 & \\
\hline 5 & 37 & 20.3 & 45 & 17.9 & \\
\hline 6 & 22 & 12.1 & 28 & 11.1 & \\
\hline \multicolumn{5}{|l|}{ Marital status } & $0.13^{* *}$ \\
\hline Single & 181 & 99.5 & 246 & 97.6 & \\
\hline Married & 1 & 0.5 & 6 & 2.4 & \\
\hline \multicolumn{5}{|l|}{ Religion" } & $0.61 *$ \\
\hline No & 43 & 24.0 & 65 & 25.9 & \\
\hline Yes & 138 & 76.0 & 186 & 74.1 & \\
\hline \multicolumn{5}{|l|}{ Father's schooling } & $0.13^{*}$ \\
\hline Incomplete elementary school & 7 & 3.8 & 12 & 4.8 & \\
\hline Complete elementary school & 10 & 5.5 & 3 & 1.2 & \\
\hline Incomplete high school & 7 & 3.9 & 12 & 4.8 & \\
\hline Complete high school & 31 & 17.0 & 43 & 17.0 & \\
\hline Complete higher education or more & 127 & 69.8 & 182 & 72.2 & \\
\hline \multicolumn{5}{|l|}{ Monthly expenses in minimum wages } & $0.29 *$ \\
\hline 1 & 7 & 4.0 & 10 & 3.7 & \\
\hline 2 & 48 & 27.1 & 80 & 32.4 & \\
\hline 3 & 59 & 33.3 & 93 & 38.2 & \\
\hline 4 & 37 & 20.9 & 37 & 15.3 & \\
\hline 5 & 26 & 14.7 & 25 & 10.4 & \\
\hline
\end{tabular}

${ }^{*} \chi^{2}$ test; ${ }^{* *}$ Fisher's exact test; "no information about 2 individuals; ${ }^{\#}$ no information about 16 individuals.

of the course, especially among men. As in the population of college students, in this sample women were prevalent $(58.1 \%)$. There were no differences between genders as to sociodemographic aspects. There were mostly single individuals, whose fathers' schooling was high, superior to $69 \%$. One quarter of the students claimed not to have a religion. It was observed that most students earned 2 or 3 minimum wages for their monthly personal expenses, while about $4.0 \%$ reported monthly expenses of less than 2 minimum wages, in both genders. 
The prevalence of CMD was of $44.9 \%$ (95\%CI 40.0-49.2). Table 2 shows the prevalence according to sociodemographic characteristics. Higher prevalence of CMD was observed among women $(46.8 \%)$ in comparison to men $(42.3 \%)$, however, this difference was not significant $(\mathrm{p}=0.35)$. The same occurred in relation to the year of the course, marital status,

Table 2. Prevalence of Common Mental Disorders according to social and demographic characteristics of medical students from Universidade Estadual Paulista “Júlio de Mesquita Filho" $(\mathrm{n}=434)$.

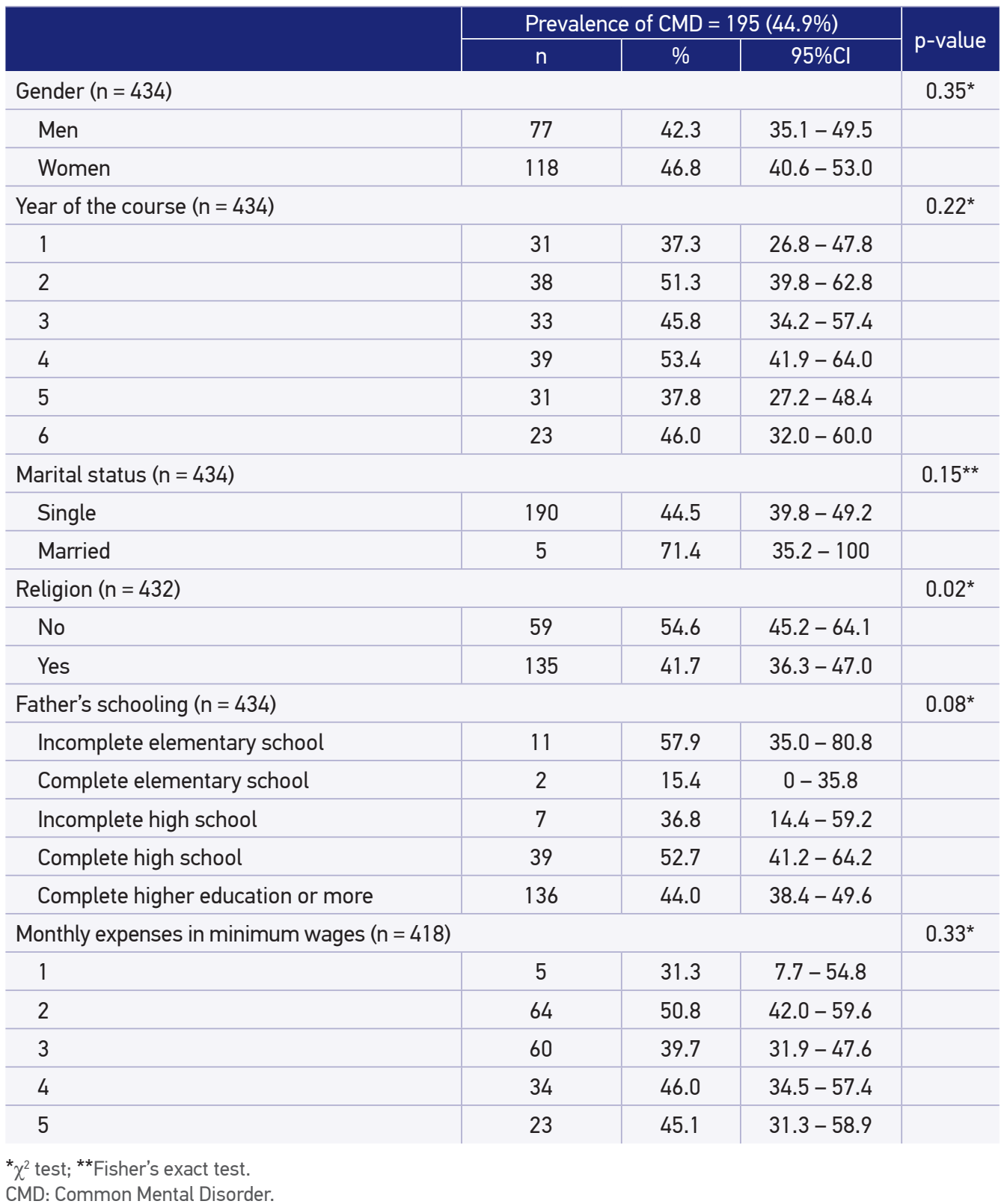


and monthly expenses in minimum wages. The fathers' schooling had a tendency to be associated with the prevalence of CMD ( $\mathrm{p}=0.08)$; however, this was not a linear tendency.

The arrangement of people in the household and the periodicity of visits to family members (Table 3) were not associated with CMD, even though the ones who visited families

Table 3. Prevalence of Common Mental Disorders according to selected variables of medical students from Universidade Estadual Paulista “Júlio de Mesquita Filho” ( $\mathrm{n}=434$ ).

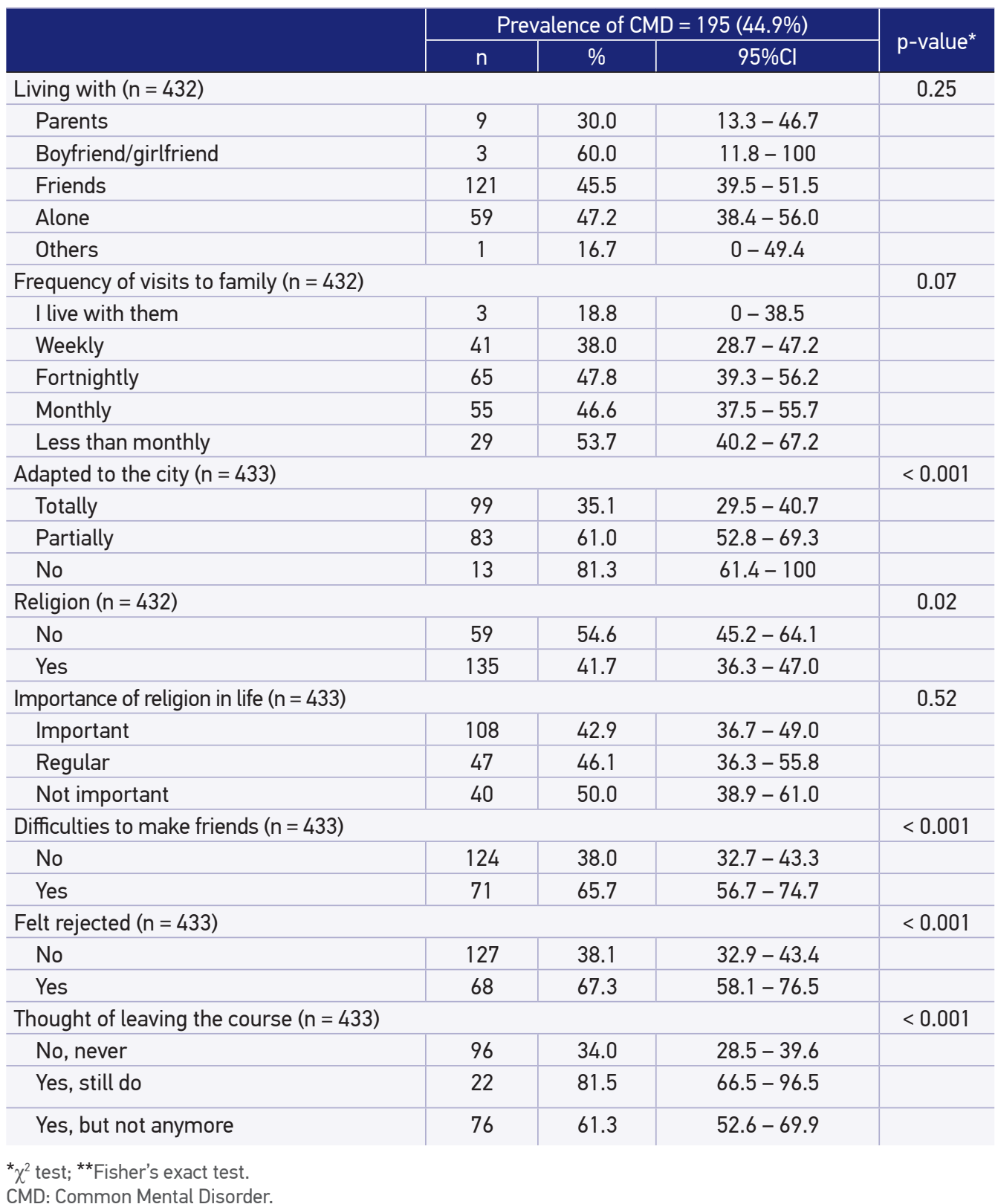


less than once a month were the only group with prevalence of CMD higher than $50 \%$ $(\mathrm{p}=0.07)$. Adaptation to the city was inversely associated with the prevalence of CMD, so totally adapted subjects had lower prevalence (35.1\%), while those who were partially adapted had prevalence of $61.0 \%$, and those who were not adapted, $81.3 \%$. Having a religion was proven to be a protective factor $(p=0.02)$, even though it was not repeated with the variable "importance of religion in your life" ( $\mathrm{p}=0.52$ ). Conditions such as difficulty to make friends and feeling rejected were associated to the higher prevalence of CMD, respectively, 65.7 and $67.3 \%$. Thinking of leaving the course was also associated with CMD, which showed the following gradation: subjects that never thought of leaving the course had the lowest prevalence (34.0\%), followed by those who thought about it but no longer do (61.3\%) and the ones who still consider the idea $(81.5 \%)$.

As observed in Table 4, all of the SSS domains proved to be strongly associated with the prevalence of CMD, with percentages higher than $60 \%$ for all of them.

The final logistic regression model for CMD is presented in Table 5. The multivariate analysis included the following variables: year of the course, marital status, father's schooling, household arrangement, frequency of visits to the family, adaptation to the city, religion, difficulty making friends, feeling rejected, thinking of leaving the course and SSS domains.

Table 4. Social support perceived among medical students from Universidade Estadual Paulista "Júlio de Mesquita Filho", according to the presence of Common Mental Disorders ( $n=434)$.

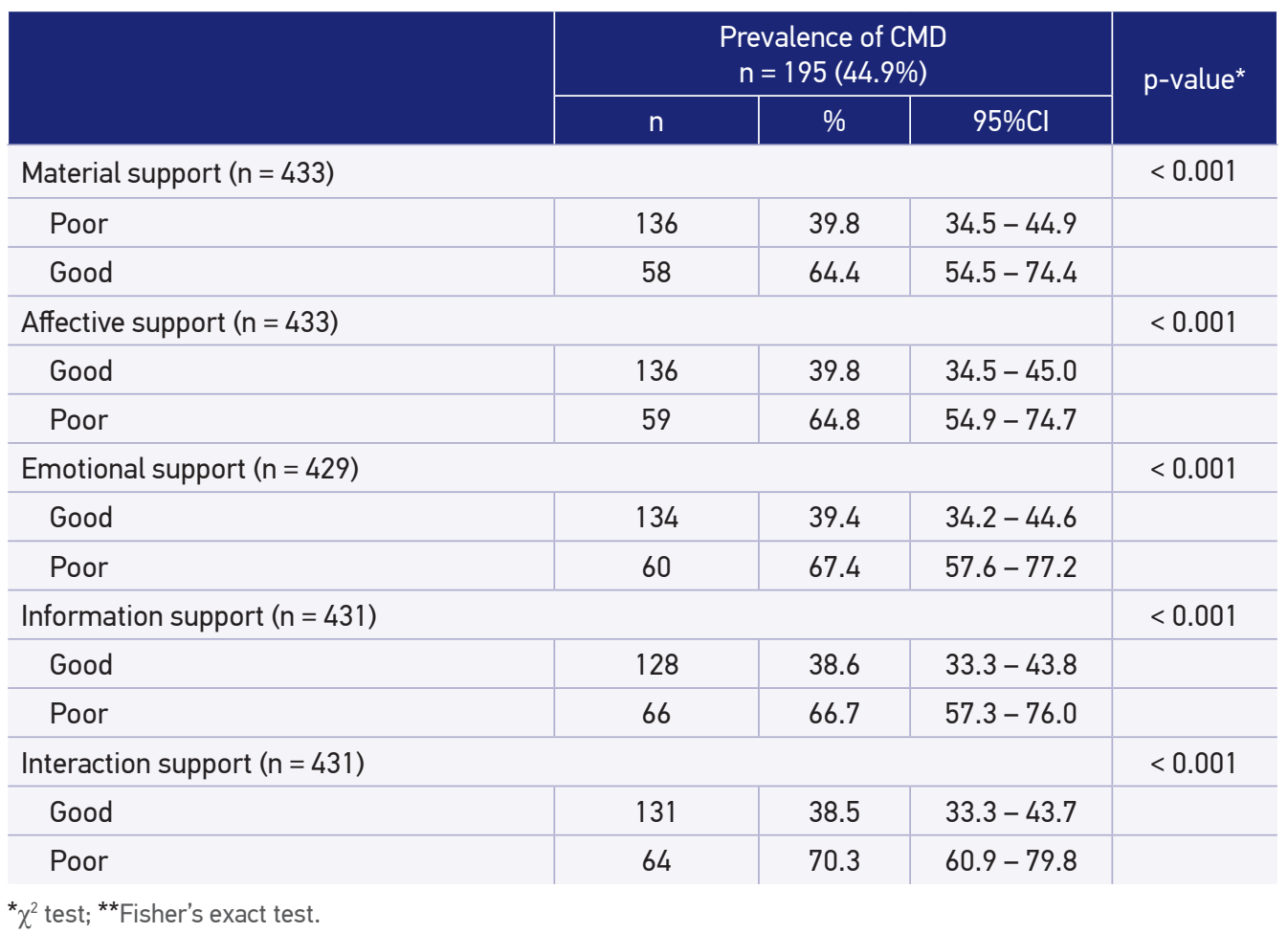

CMD: Common Mental Disorder. 
Table 5. Final Logistic Regression model for the presence of Common Mental Disorders among medical students from Universidade Estadual Paulista "Júlio de Mesquita Filho".

\begin{tabular}{|c|c|c|c|c|c|}
\hline & Crude OR & $95 \% \mathrm{Cl}$ & Adjusted OR & $95 \% \mathrm{Cl}$ & p-value* \\
\hline Felt rejected & & & & & $<0.001$ \\
\hline $\mathrm{No}^{\#}$ & 1 & & & & \\
\hline Yes & 3.3 & $2.1-5.3$ & 2.5 & $1.5-4.2$ & \\
\hline \multicolumn{6}{|c|}{ Thought of leaving the course } \\
\hline No, never\# & 1 & & & & $<0.001$ \\
\hline Yes, but not anymore & 3.1 & $2.0-4.7$ & 2.6 & $1.6-4.2$ & \\
\hline Yes, still do & 8.5 & $3.1-23.2$ & 6.9 & $2.4-19.4$ & \\
\hline Material support & & & & & 0.06 \\
\hline Good $^{\#}$ & 1 & & & & \\
\hline Poor & 2.7 & $1.7-6.2$ & 1.7 & $1.0-2.9$ & \\
\hline \multicolumn{6}{|l|}{ Interaction support } \\
\hline Good $^{\#}$ & 1 & & & & 0.002 \\
\hline Poor & 3.8 & $2.3-6.2$ & 2.4 & $1.4-4.2$ & \\
\hline
\end{tabular}

*Wald's test; "reference categories.

OR: Odds Ratio.

In the final model, there were only: "interaction" dimension of social support $(\mathrm{p}=0.002)$, thinking of leaving the course $(\mathrm{p}<0.001)$ and feeling rejected $(\mathrm{p}<0.001)$. It was considered as important to maintain material support in the model, even though it presented a nonsignificant result considering $\mathrm{p}=0.05$ in order to control the analysis for this factor too.

\section{DISCUSSION}

In this study, the prevalence of CMD was of $44.9 \%$, very similar to the one obtained in a previous study (44.6\%), with students from the same college ${ }^{21}$, as proposed in the hypotheses of this research. However, the prevalence was higher than the one found for other medical students in investigations that also applied the SRQ-20 ${ }^{15,16,18.20}$. It is possible that local characteristics, related to the structure of the course or even to regional variations, respond for these differences. In population studies conducted in Brazil, the prevalence of CMD is similar to that found here, and sometimes lower. In the study by Rocha et al. ${ }^{13}$, the prevalence of CMD among inhabitants of Feira de Santana, Bahia, was of 29.9\%. However, it is important to mention that the sample in the study from Bahia included subjects with ages ranging from 15 to more than 70 years old, with very significant income variations, and these are considered to be risk factors for CMD. The students in this study were young, 
probably healthy and with higher income in relation to the general population, which leads to the assumption that they live in more favorable conditions and that the prevalence of mental distress should be inferior in comparison to the general population.

After the multivariate analysis, the following were independently associated with CMD: thinking of leaving the course, feeling rejected and the domain interaction support of SSS.

By comparing these data with the ones obtained by Lima et al. ${ }^{21}$, it is observed that the household arrangements did not show substantial changes: subjects living with friends were prevalent, followed by those who lived alone. However, studies conducted in the 1980 s for the group of students in the same campus show there was an increase in the number of individuals living alone ${ }^{31}$. The socioeconomic conditions of these students are more favorable than the ones found for the general population, and their families also present with high schooling, and these aspects had already been identified in previous studies with medical students ${ }^{12,21}$.

One of the most frequent findings in literature concerning the presence of CMD is the association with the female gender and with worse life conditions, and these factors are not associated with CMD in this study. Probably, life conditions - identified here by the socioeconomic indicators - are very similar in the set of students included in this study. Therefore, by considering the homogeneity of the sample in relation to this parameter, small differences were not detected in the analyses. It is important to mention, however, that material support, measured by SSS, showed strong tendency to be associated with the high prevalence of CMD.

The comparison between the prevalence of CMD with regard to gender revealed no differences, which is in accordance with the results observed by other authors ${ }^{15,21}$. It is possible that, in groups of university students, differences between genders are not so explicit to be captured by screening instruments such as the SRQ-20, considering the approximation of the social roles of men and women in the routine of the university life.

The single association with the domain "interaction support", and not to the others, calls the attention. This domain intends to assess the "availability of people to have fun and relax with" 27 . According to Costa and Pereira ${ }^{32}$, inside the broad set of stressors faced by the students during the medical course, there are some inevitable ones, such as dealing with the pain and suffering of the patients. However, there is also a set of avoidable stressors, which concern the structure of the course and the relationship between peers and the school staff ${ }^{2}$. It is possible that students who do not dispose of "people to have fun and relax with" are more lonely and do not develop fighting strategies, such as the "search for social support" to combat the stressors they are facing with during the course. Zonta et al. ${ }^{33}$ conducted a qualitative study about the strategies to face stress developed by medical students in Universidade Federal de Santa Catarina, and they point to the value of interpersonal relationships with relatives, boyfriend or girlfriend and friends among the strategies used by the students to fight possible stressors.

Because of some characteristics of this study, its results should be seen with limitations. The first one concerns the cross-sectional nature of the study, which prevents suppositions about causality $^{34}$, since the information about the outcome and explanatory variables are investigated 
simultaneously. It is also considered that the obtained data are limited in relation to its external validity. Even though the aspects of medical courses in Brazil are similar (full time course, which leads most of the students to depend on family members, among other characteristics), the results obtained in this study may not be generalized for all of the students. It is more likely that the courses conducted in medium-sized cities, which become the destination for most students who will attend the courses, would present similar results, since, for these young people who are far away from their families, social support from colleagues becomes more important. Finally, one last limitation refers to the fact that specific aspects of the medical course were not investigated, as well as possible abusive situations to which the students may have been submitted (haze, excessive demand for performance by authoritarian means etc.). A recent study conducted in the medical school of Ribeirão Preto showed that changes in the curricular structure were associated to lower levels of anxiety, when pedagogical strategies more focused on the students were implemented ${ }^{7}$. As to the matter of abuse, Wolf et al. ${ }^{35}$ had already noticed the association between such situations and depression and anxiety among medical students assessed in the four first years of the course. These aspects should be considered in further studies about mental health of the medical students and also in other fields of health.

One of the Strong points in this study consisted of the expressive participation of students. This result was probably owed to field planning, but it can also demonstrate the receptiveness of students to the investigations about their life conditions. The lower percentage of participation of students in the sixth year can be attributed to the fact that the internships in this phase are made in different locations, which may have prevented the participation of some students.

The association of social support with the higher prevalence of CMD found in this study suggests that strategies should be developed to stimulate and provide more interaction between students. As an example, mentoring programs, psychological support services and even the development of new pedagogical proposals that would stimulate and create interactive learning processes can help decrease the prevalence of mental distress. It is also possible that teaching strategies focused on the student, developed in small groups with the more active participation of students in their learning process, would favor more interaction between them, therefore making the environment healthier.

\section{REFERENCES}

1. Adlaf EM, Gliksman L, Demers A, Newton-Taylor B. The prevalence of elevated psychological distress among Canadians undergraduates: findings from the 1998 Canadian Campus Survey. J Am Coll Health 2001; 50(2): 67-72.

2. Nogueira-Martins LAN. Morbidade psicológica e psiquiátrica na população médica. Bol Psiquiatr 1990; 22-23: 9-15.

3. Hahn M, Ferraz MPT. Características da clientela de um programa de saúde mental para estudantes universitários brasileiros. Rev ABP-APAL 1998; 20(2): 45-53.
4. Dyrbye LN, Thomas MR, Shanafelt TD. Systematic review of depression, anxiety, and other indicators of psychological distress among U.S. and Canadian medical students. Acad Med 2006; 81(4): 354-73.

5. Millan LR, Azevedo RS, Rossi E, De Marco OLN, Millan MPBM, de Arruda PCV. What is behind a student's choice for becoming a doctor? Clinics (Sao Paulo) 2005; 60(2): 143-50.

6. Lima MCP. O psicodrama e o ensino médico: reflexões a partir de uma experiência prática. Rev Bras Psicodrama 1997; 5(1): 11-9. 
7. Zuardi AW, Prota FDG, Del-Bem CM. Reduction of the anxiety of medical students after curricular reform. Rev Bras Psiquiatr 2008; 30(2): 136-8.

8. McCue JD. The effects of stress on physicians and their medical practice. N Engl J Med 1982; 306(8): 458-63.

9. Nogueira-Martins LAN. Atividade médica: fatores de risco para a saúde mental do médico. Rev Bras Clín Terap 1991; 20(9): 355-64.

10. Goldberg D, Huxley P. Common mental disorders: a biosocial model. 2nd edition. Tavistock: Routledge; 1993.

11. Organização Mundial da Saúde. Classificação Internacional das Doenças - Organização Mundial da Saúde. $10^{a}$ edição. Porto Alegre: Artes Médicas; 1993.

12. Ferreira RA, Peret Filho LA, Goulart EMA, Valadão MMA. O estudante de medicina da Universidade Federal de Minas Gerais: perfil e tendências. Rev Assoc Med Bras 2000; 46(3): 224-31.

13. Rocha SV, Almeida MMG, Araujo TM, Virtuoso Jr JS. Prevalence of common mental disorders among the residents of urban areas in Feira de Santana, Bahia. Rev Bras Epidemiol 2010; 13(4): 1-11.

14. Fonseca MLG, Guimarães MBL, Vasconcelos EM. Sofrimento difuso e transtornos mentais comuns: uma revisão bibliográfica. Rev APS 2008; 11(3): 285-94.

15. Hidalgo MPL, Ponte TS, Carvalho CG, Pedrotti MR, Nunes PV, Souza CM, et al. Association between mental health screening by self-report questionnaire and insomnia in medical students. Arq Neuropsiquiatr 2001; 59(2-A): 180-5.

16. Volcan SMA, Sousa PLR, Mari JJ, Horta BL. Relação entre bem-estar espiritual e transtornos psiquiátricos menores: estudo transversal. Rev Saúde Pública 2003; 37(4): 440-5.

17. Facundes VLD, Ludermir AB. Common mental disorders among health care students. Rev Bras Psiquiatr 2005; 27(3): 194-200.

18. Souza FGM, Menezes MGC. Estresse nos estudantes de Medicina da Universidade Federal do Ceará. Rev Bras Educ Méd 2005; 29(2): 91-6.

19. Fiorotti KP, Rossoni RR, Borges LH, Miranda AE. Transtornos mentais comuns entre os estudantes do curso de medicina: prevalência e fatores associados. J Bras Psiquiatr 2010; 59(1): 17-23.

20. Almeida AM, Godinho TM, Bitencourt AGV, Teles MS, Silva AS, Fonseca DC, et al. Common mental disorders among medical students. J Bras Psiquiatr 2007; 56(4): 245-51.

21. Lima MCP, Domingues MS, Ramos-Cerqueira ATA. Prevalência e fatores de risco para transtornos mentais comuns entre estudantes de Medicina. Rev Saúde Pública 2006; 40(6): 1035-41.
22. Berkman LF, Glass T, Brissette I, Seeman TE. From social integration to health: Durkheim in the new millennium. Social Sci Med 2000; 51(6): 843-57.

23. Rospenda KM, Halpert J, Rochman JA. Effects of social support on medical students' performances. Acad Med 1994; 69(6): 496-500.

24. Sreeramareddy CT, Shankar PR, Binu VS, Mukhopadhyay C, Ray B, Menezes RG. Psychological morbidity, sources of stress and coping strategies among undergraduate medical students of Nepal. BMC Med Educ 2007; 7: 26.

25. Instituto Brasileiro de Geografia e Estatística. Censo Demográfico 2010. Disponível em http:/ / www. ibge.gov.br/home/ estatistica/populacao/ censo2010 (Acessado em 22 de abril de 2012).

26. Griep RH, Chor D, Faerstein E, Lopes CS. Apoio social: confiabilidade teste-reteste de escala no estudo prósaúde. Cad Saúde Pública 2003; 19(2): 625-34.

27. Griep RH, Chor D, Faerstein E, Werneck GL, Lopes CS. Validade de constructo de escala de apoio social do Medical Outcomes Study adaptada para o português no estudo pró-saúde. Cad Saúde Pública 2005; 21(3): 703-14.

28. Mari JJ, Williams P. A validity study of a psychiatric screening questionnaire (SRQ-20) in primary care in the city of Sao Paulo. Br J Psychiatry 1986; 148: 23-6.

29. Statacorp. Stata Statistical Software: Release 10.0. College Statio, TX: Stata Corporation; 2007.

30. Kleinbaum DG, Logistic regression: a self-learning text. New York: Springer; 1994.

31. Soler JMP, Curi PR. Caracterização geral do universitário da Unesp, campus de Botucatu - SP, 1980. Ciênc Cult (São Paulo) 1981; 13(9): 1239-45.

32. Costa LSM, Pereira CAA. O abuso como causa evitável de estresse entre estudantes de medicina. Rev Bras Educ Med 2005; 29(3): 185-90.

33. Zonta R, Robles ACCM, Grosserman S. Estratégias de enfrentamento do estresse desenvolvidas por estudantes de medicina da Universidade Federal de Santa Catarina. Rev Bras Educ Med 2006; 30(3): 147-53.

34. Prince M. Cross-sectional surveys. In: Prince M, Steward R, Ford T, Hotopf M. Practical psychiatric epidemiology. Oxford: Oxford University Press; 2003. p. 111-29.

35. Wolf TM, Scurria PL, Webter MG. A four-year study of anxiety, depression, loneliness, social support, and perceived mistreatment in Medical students. J Health Psychol 1998; 3(1): 125-36.

Received on: 09/13/2011

Final version presented on: 04/27/2012

Accepted on: 05/23/2012 